\title{
Environmental ethics, bioethics and education
}

\author{
Christos A. Tsekos, Demetrios P. Matthopoulos
}

Research Group on Environmental Ethics, Department of Environmental and Natural Resources Management, University of Patras, Greece

\section{Email address:}

ca.tsekos@yahoo.com (C. A. Tsekos),dmatthop@upatras.gr (D. P. Matthopoulos)

\section{To cite this article:}

Christos A. Tsekos, Demetrios P. Matthopoulos. Environmental Ethics, Bioethics and Education. American Journal of Life Sciences. Vol. 2, No. 1, 2014, pp. 1-4. doi: 10.11648/j.ajls.20140201.11

\begin{abstract}
Environmental Ethics and Bioethics are two fast evolving sections of Applied Ethics. Issues that are related to Environmental Ethics and Bioethics include Cloning, Genetically Modified Organisms, and Euthanasia. Their teaching, despite two main constraints, is gradually introduced in the formal Educational System of various countries. The one constrain is the uncertainty that characterizes Environmental and Biological phenomena that creates gnoseological problems with regard to Life itself. The other is the natural complexity of the ethical dilemmas arising in these fields. Therefore, a problem that arises is to find the best way in order to teach these ambiguous issues. We are presently attempting to initially analyze these topics, in order to propose a new way to teach the above ambiguous issues.
\end{abstract}

Keywords: Teaching, Biological Issues, Environmental issues, Uncertainty, Moral Dilemmas, Moral Development, Kohlberg

\section{Introduction}

Environmental Ethics and Bioethics are two fast evolving but relatively close sections of Philosophical Ethics. They actually comprise part of Applied Ethics, each one having its own evolution and history. Their flourishing is the result of the scientific and technological progress and their applications in our daily life.

Then it comes into question the relation between the human beings and the non-human environment. Environmental Ethics has succeeded to widen our ethical speculations, so that to include the entire non human world. As a distinctive scientific section systematically evolved in the early 70's attempting to study species' and ecosystems' inherent value, population ethics and inter-generational justice $[1,2]$.

This inherent value is the result of the evolutionary development of species, positioning them in defined ecosystems. Studying each species independently usually provides us with false ideas in relation to their own value in the defined ecosystems. This naturally derived inherent value that characterizes all living organisms, despite their taxonomy, is better described by the Greek word "autaxia". "Autaxia" is a self value that is independent of the value attributed to various living or non-living systems by humans. Values attributed by humans are related to the particular interest that we, humans, foster for our own benefit.
Bioethics according to Bryant et al. [3] and Levine [4] was introduced as a term by Rensselaer Van Potter in the early 70's [5,6]. However, according to Lolas [7], the first document that uses the word "Bioethics" dates back to 1927, when Fritz Jahr, a protestant pastor and theologian from Halle, gave the title "Bio-Ethik: Eine Umschau ilber die ethischen Beziehungen des Menschen zu Tier und Pflanze" to an article published in the Journal Kosmos [8]. Van Potter notes that "When I used the term "bioethics", therefore, I clearly meant it to include not simply medical ethics, but environmental and agricultural ethics as well. Indeed, the word speaks for itself. ... 'Bioethics' must continue to mean the application of ethics to all life" [9].

Bioethics deals with ethical issues springing up during the application of Life Sciences. Such issues are the use of laboratory animals in research, the development and use of genetically modified organisms, gene therapy, euthanasia and others $[10,11]$. In certain countries, such as Great Britain, USA and Canada, Bioethics has already been introduced in High School and University curricula, while in other countries, such as India, China and Philippines, according to Macer [12] is being gradually introduced. UNESCO in 2006 adopted the Bioethical statute "Universal Declaration on Bioethics and Human Rights", which among other issues proposes to Member Countries the introduction 
of teaching Bioethics in all educational levels. One of the goals, according to the declaration, is to "promote the respect of human personality, the human rights and the respect of the life of all human beings" [13].

The present study aims in investigating possible ways to teaching the ambiguous bioethical issues, having initially evinced the complexity of dilemmas arising in Environmental Ethics and Bioethics.

\section{Education}

Diverse opinions with regard to the aim, the ways and the content of Education have been expressed in the various philosophical movements. A.N. Whitehead, a Neorealist, expresses opinions that are closely related to the ones of Realists and those belonging to the movement of New Education. Whitehead was one of those that stood up the importance that needs to be attributed during the educational process to the contemporary needs and interests of the pupil as well as the importance of learning by doing. These ideas drive him closer to certain Realists such as John Dewey and William Kilpatrick. However, there are philosophical movements where opposing opinions exist among their members. Such is the case of A. Schopenhauer who proposed that the main endeavour of the educational process should always let particular observations precede general ideas and not vice versa [14]. According to Schopenhauer the human intellect general ideas arise from particular observations, and therefore come after them in point of time [15]. Thus the aspects of those two idealists' philosophers, Schopenhauer and Plato, oppose each other.

Despite the influence of the various philosophical movements over the years on Education, there is a tendency the educational aims to be implemented via teaching. However, although there is no consensus on teaching aims, according to Kapsalis [16], it is generally accepted that they are shaped by the following:

a) Aims directed towards the cognitive development of learner, which are focused towards the transmission of knowledge

b) Emotional ones directed in shaping values, interests and behaviours

c) Psychokinetic ones directed towards the development of kinetic skills, such as the ability to perform experiments and so on.

This general classification of aims is certainly logical, as long as there is no way to grow learner's psychological abilities without the simultaneous transmission of knowledge. As a consequence to the previously referred, in trying to transmit knowledge, the psychological abilities of the learner are developed in parallel.

Thus, teaching issues regarding Environmental Ethics and Bioethics, the learner acquires knowledge, while in parallel he has the opportunity to develop, in other words to "shape", his emotional and psychokinetic functions.

\section{Gnoseological Issues in Biological and Environmental Sciences}

It is generally admitted that Technology is advancing very fast. Very often its achievements resemble god Janus that is to say that they are bifacial. They possess advantages, while in the meantime they carefully hide certain disadvantages. Such a contemporary issue of biological and environmental sciences is the controversial issue of the genetically modified organisms.

Nowadays transferring genes among species it is a common process. Thus scientists are able of developing genetically modified organisms (plants, animals or microorganisms). Many scientists, as well as many people, have publicly expressed their objections in relation to the dangers that may appear from applying such technologies. Such worries are referred to genes introduced to the food chain and the possibility of implications to the immune system, i.e. the emergence of allergies [17]. However, it should be noted that until now there are not enough data with regard to the negative implications of transgenic organisms. An analysis of this issue has been carried out by Pavone, Goven and Guarino [18]. They noted that, assessing the impact of introducing transgenic organisms, social and political issues should be incorporated. They are actually referring that "... therefore, molecular effects of genetic manipulation are unpredictable like those on natural mutations occurring in natural breeding" [18].

It is difficult to predict the impact of large-scale technological innovation at a moment that it is difficult to predict and evaluate the effects of small-scale, local activities (e.g., the artificial heart) $[19,20]$. This is a an example just to evince the uncertainty, with regard to the impact, that sometimes accompanies scientific innovations and thus the difficulties we face when it comes the time to teach such concepts.

In addition, there are deeper gnoseological issues with regard to Life itself. There are scientists that accredit to Life certain characteristics that are just enough to distinguish Life from the non living matter. However, there are implicitly life forms, i.e. viruses, which exist on the borderline between living and non-living matter that in order to initiate their life-cycle they borrow the functions of living organisms [21].

How could we then define the borderline that determines Life? It is rather difficult to approach this issue without being deceitful. Philosophers attempted to study the concept of Life but, as Smart (1963) and Beatty (1995) stated, in Biology the Laws that have general validity are few or non existent [22]. 


\section{Ethical Issues that Arise from the Rapid Development of Biological and Environmental Sciences}

The technological progress of the last half of the twentieth century brought into surface issues that Environmental Ethics and Bioethics deal with. The positive and negative outcomes of technological progress comprise an issue in itself that is difficult to be objectively assessed. This issue forced intellectuals, such as Umberto Eco, to declare that the idea of scientific and technological progress could be the medium towards Humanity's liberation [23]. However, despite someone's tendency to defend Technology, he cannot overlook the fact that we are in the era that humanity is surrendered, is depended on so to say, to the "miracles" of Technology. Thus, we are heading towards an era that we draw away from "Being" while we are alienated by "Having", that leads to the "maximal impoverishment of our inner self" as Marcel would say [24]. Unfortunately, regardless the help offered to contemporary practical problems by Technology, it often leads to a surveillance of Life (human and non-human one) as a soulless object without intrinsic value (autaxia). For instance, the pre-natal diagnosis undoubtedly has greatly contributed to premature diagnosis and in consequence to the treatment of serious illnesses developed in certain embryos [25]. In the UK all new-born babies are tested for phenylketonuria and congenital hypothyroidism, because early detection allows the establishment of treatment and management programmes that will eliminate or at least alleviate the negative effects of these conditions [3]. Is it possible for someone to imagine the consequences in case that information on somebody's genetic predisposition to certain serious disease ever comes across to his employers or insurance companies? It is obvious that there is a serious threat to the referred person as a result of Technology. Let us proceed one step forward and wonder if it is ethical to develop, under the auspices of Technology, more clever people or "custom made" humans that would never have the right to be asked about their "brand new" body and consequently their future. Under these circumstances, is it possible that we are approaching the time of "Superhuman"?

As stated above, many of the issues that Bioethics and Environmental Ethics are dealing with results from the rapid advancement of scientific and technological innovation in our time. In the meantime, there are further issues that they are engaged with that, although they are not related to technological advancement, they generate serious ethical dilemmas. Let us consider the case of a diseased person pledging for "Euthanasia". What would we consider more valuable? The divine gift of life or the disburdenment from pain of the diseased person?

It becomes obvious that there is a difficulty in trying to give answers to the ethical dilemmas that Bioethics and Environmental Ethics are dealing with.

\section{How Environmental Ethics and Bioethics Should Be Taught}

Bioethics and Environmental Ethics, due to their subjectivity, are considered as a "challenge" for Education. From this point of view, the question that arises is "which is the best way to teach such subjects so that indoctrination to be avoided, but in the meantime to achieve the ethical maturation of trainees?"

Piaget and Kohlberg greatly contributed to this direction. Kohlberg's ideas, with regard to the development of morality, mastered for decades [26, 27]. He actually recommended the development of the ethical personality by the introduction of ethical dilemmas in the educational process that would gradually lead the trainee to his moral maturation $[28,29]$. Such ethical dilemmas need to have more than one solution. They need to be based on the appropriate cognitive subject. Their alternative solutions, the way to be realized and their consequences need to be discussed so that trainees to develop their own moral concepts. An example of such a dilemma that could be used in teaching is the following:

"Earth's overpopulation is a universal problem. The population in many developing countries rises exponentially. Let us consider that in one of the developing countries, despite institutional efforts, such as financial motivations or Planned Parenthood advising programs, the problem of overpopulation persists. Is it morally correct the Government to ban couples to have a second child?"

As mentioned above, due to the specific character of Bioethics and Environmental Ethics, the danger of indoctrination lies in wait always. Introducing ethical dilemmas into the teaching of such issues, the learner is provided with the opportunity to select between different options and consequently to become aware of the difficulties in resolving real life dilemmas.

\section{Conclusions}

Bioethics and Environmental Ethics nowadays bring into focus issues as diverse as human and animal cloning, stem cell research, climatic change and the relationship between human beings and nature to name but a few of them. Contemporary scientific and technological achievements are changing our daily life dramatically and it seems very difficult to find clear cut solutions and answers for all the types of ethical dilemmas that arise. We strongly believe that "discussion" on such issues has to include as many social groups as possible. Andrew Light (inspired by the principles of Environmental Pragmatism) perfectly noted that Environmental Philosophy's main task is "to convince policy makers to formulate better policies and make the case to the public at large to support these policies for ethical reasons" [30]. In our opinion, this ought to be the key note in Environmental Ethics and Bioethics, in order for them to make a more tangible contribution to the solution of environmental and bioethical problems. 
Dialogues and discourse among Philosophers regarding Values and Morality of course have an inherent value, i.e. a value in itself, but Society's involvement in bioethical and environmental issues are of greater importance. Consequently, as it is obvious, Education could play a vital role in familiarising society (young people in this particular case) with these issues.

Despite the effort that human mind pays to conceive the notion of Truth, in its pure state through Science and Technology, it is rather possible that it will stay a mixture of objectivity and subjectivity. The difficulty in accessing Truth must not discourage contemporary Knowledge wayfarers to their wander. In the $16^{\text {th }}$ century Descartes declared the famous de omnibus dubitandum on his effort to attribute ambiguity not as purpose but as the starting point of philosophical reflection. This "maybe" that ambiguity bears as a notion is the "salt" of Philosophy. Contemporary Education, relying on this "maybe" and having as starting point the ambiguity and the dialogue, is able to assist the trainee to develop his own reviewing spirit away of certainty and dogmatism.

\section{References}

[1] C. Palmer, "An overview of Environmental Ethics," in Environmental Ethics: an anthology, A. Light and H. Rolston, Eds. Oxford, Malden and Carlton: Blackwell Publishing, 2003, pp. 15-37.

[2] R. Attfield, Environmental Ethics. Cambridge: Polity Press, 2003.

[3] J. Bryant, L. Baggott and J. Searle, Bioethics. Chichester: J. Wiley \& Sons, 2006.

[4] C. Levine, "Analyzing Pandora's Box: the History of Bioethics," in The Ethics of Bioethics: mapping the moral landscape, Lisa. A. Eckenwiler and Felicia G. Cohn, Eds. Baltimore: The Johns Hopkins University Press, 2007, pp. 3-23.

[5] R. Van Potter, "Bioethics: The Science of Survival," Perspectives in Biology and Medicine, Vol. 14, pp. 127-153, 1970.

[6] R. Van Potter, Bioethics: Bridge to the Future. New Jersey: Prentice Hall, 1971.

[7] F. Lolas, "Bioethics and animal research. A personal perspective and a note on the contribution of Fritz Jahr," Biological Research, Vol. 41, pp. 119-123, 2008.

[8] F. Jahr, "Bio-Ethik. Eine Umschau über die ethischen Beziehungen des Menschen zu Tier und Pflanze," Kosmos. Handweiser für Naturfreunde, Vol. 24, pp. 2-4, 1927.

[9] R. Van Potter, "What Does Bioethics Mean?" The Ag Bioethics Forum, Vol. 8 (1), p.2, 1996.

[10] P. Singer and H. Kuhse (Eds.), Bioethics: An anthology. Oxford and Malden: Blackwell Publishing, 1999.

[11] B. Steinbock (Ed.), The Oxford Handbook of Bioethics.
Oxford: Oxford University Press, 2007.

[12] D. Macer, "Bioethics education for informed citizens across cultures," School Science Review, Vol. 86, pp. 83-86, 2004.

[13] United Nations Educational and Cultural Organization (UNESCO), Universal Declaration on Bioethics and Human Rights, UNESCO, Paris, 2006.

[14] A. Schopenhauer, Studies on Pessimism (translated by T.B. Saunders). New York: Cosimo, 2007.

[15] A. Schopenhauer, Parerga and Paralipomena (translated by E.F.J. Payne). Oxford: Oxford University Press, 2000.

[16] A. Kapsalis, Educational Psychology. Thessaloniki: Kyriakidis Brothers, 2000.

[17] F.T. Budinger and M.D. Budinger, Ethics of Emerging Technologies: scientific facts and moral challenges. New Jersey: J. Wiley \& Sons, 2006.

[18] V. Pavone, J. Goven and R. Guarino "From risk assessment to in-context trajectory evaluation - GMOs and their social implications," Environmental Sciences Europe, Vol. 23, p. 3, 2011.

[19] D. Jamieson, "The artificial heart: Reevaluating the investment," in Organ Substitution Technology, D. Mathieu, Ed. Boulder: Westview Press, 1988, pp. 277-296.

[20] D. Jamieson, "Ethics, Public Policy and Global Warming," in Environmental Ethics: an anthology, A. Light and H. Rolston, Eds. Oxford, Malden and Carlton: Blackwell Publishing, 2003, pp. 371-379.

[21] G. Malacinski, Essentials of Molecular Biology. Sudbury: Jones and Bartlett Publishers, 2002.

[22] E. Mayr, This is Biology - The Science of Living World. Cambridge: Harvard University Press, 2002.

[23] U. Eco, Semiotics in everyday life. (A collection of papers by Umberto Eco). A. Malliaris Editions: Thessaloniki, 1999.

[24] G. Marcel, Etre et avoir. Paris Aubier-Montaigne, 1935.

[25] D. Kaplan, "Prenatal Screening and its Impact on Persons with Disabilities," in Bioethics: An anthology, H. Kuhse and P. Singer, Eds. Oxford and Malden: Blackwell Publishers, 1999, pp. 130-136.

[26] J. Rest, D. Narvaez, S. Thoma and M. Bebeau, "A-Neo Kohlbergian Approach to Morality Research," Journal of Moral Education, Vol. 29 (4), pp. 381-395, 2000.

[27] J.D. Hunter, The death of Character: moral education in an age without good or evil. New York: Basic Books, 2000.

[28] L. Kohlberg, 1981, Essays on moral development, Vol. 1: The Philosophy of Moral Development. New York: Harper \& Row, 1981.

[29] L. Kohlberg, 1984, Essays on moral development, Vol. 2: The nature and validity of moral stages. San Francisco: Harper \& Row, 1984.

[30] A. Light. 2003, "Ecological Restoration and the Culture of Nature: a Pragmatic Perspective," in Environmental Ethics: an anthology, A. Light and H. Rolston, Eds. Oxford, Malden and Carlton: Blackwell Publishing, 2003, pp. 398-411. 